\title{
Students' Perception and Preferences of Written Feedback in Academic Writing
}

\author{
Amelia Alfred Tom \\ Universiti Teknologi MARA \\ Email: ameliaalfred@sarawak.uitm.edu.my \\ Affidah Morni \\ Universiti Teknologi MARA \\ Email: affidah75@sarawak.uitm.edu.my \\ Lilly Metom \\ Universiti Teknologi MARA \\ Email: lillymetom@sarawak.uitm.edu.my \\ Saira Joe \\ Universiti Teknologi MARA \\ Email: saira03@sarawak.uitm.edu.my
}

\section{Doi:10.5901/mjss.2013.v4n11p72}

\section{Abstract}

Writing in a second language is not an easy task for students. Yet, it is an important skill for them to acquire in order to succeed in university. The aim of this study is to investigate ESL tertiary students' perception on the importance and effectiveness of written feedback in their academic writing assignments. The study also aims to examine students' preferred feedback in helping them revise and improve their written assignments. The subjects are 34 Diploma students. Data was gathered via a questionnaire adapted from Ferris (1995), Leki (1999) and Hedgecock and Leftkowitz (1994). Findings reveal that students view feedback as important and necessary to help them improve their writing ability. Findings also revealed that students prefer feedback in the form of grammar correction and suggestions on how to improve. The least preferred feedback are questions and one-word comments.

Keywords: Learner perceptions, learner preferences written feedback

\section{Introduction}

The traditional approach to writing has been interested mainly in the final product of students' text. Teachers were concerned with how well students are able to write error free sentences. This approach is called the product approach where the focus is on students' ability to use the target language competently and fluently. This approach believes that students should be taught how to form and write grammatically correct sentences before they are able to produce a piece of writing (Nunan, 2000).

In the product approach writing classes, students are given writing assignments, which are handed in to their teacher to be corrected as a final product. The assignment is corrected and returned by the teacher with the hope that students will remember their mistakes and avoid repeating it in the next writing assignment. The advantage of this is students' ability to write increases as they are provided with models of writing. However, it often see little awareness from the students of their mistakes as most of the time students will put their papers away and forget about the comments given. More recently, a new approach to writing called the process approach emerged. This approach introduces a different way of dealing with the complexity of producing a good piece of writing. In this approach, writing is seen as a recursive process that involves a lot of planning, drafting and redrafting of ideas.

A direct result of the emergence of process writing is the many ways by which a teacher can help students to formulate their ideas. In addition, teachers are able to provide them with an audience's view of their text. Such 
intervention can come in the form of teacher-student conferences, peer feedback, taped commentary (Hyland, 1990) students' self-monitoring technique (Charles, 1990) or teacher written feedback. All these technique provide different ways of responding to students' writing. The main aim of all these techniques is that the responses or feedback given by the teacher will help to improve students' writing ability and minimise the repetition of mistakes. In addition, the emergence of process writing also sees revision as central in the teaching of writing (Zamel, 1982: 206) particularly in a process writing class. How students revise is greatly influenced by the way they perceive their teacher's comments. It is therefore necessary that the teachers provide students with appropriate feedback that can help them to improve their writing ability.

\subsection{Significance of the study}

The study is carried out with the hope that both teachers and students will be aware of the types of written teacher feedback that students prefer as well as feedback that will help students revise effectively. It is also the aim of this study to find out what causes students' tendency to repeat their mistakes despite attempts by their teachers to raise their awareness towards those mistakes.

Previous studies have looked at the roles of teachers and how teachers are to respond to students' writing. Based on the findings of previous studies, many theories have come up in order to ensure that feedback is effective in helping students develop their writing ability. Among them, teachers are advised to take the role of a reader, coach, facilitator and guide. Teachers are also advised to prioritise their comments as well as provide a balance of both praise and criticism.

Past researches have also looked at students' reactions to teacher feedback and their perception towards it. However, most of the studies available were carried out in the West. There are a limited number of researches on written teacher feedback in Malaysian ESL context. Moreover, much of it what is available is studies on L1 or studies in L2 that are based on L1. Therefore it is still vague as to whether local ESL students have the same view of teacher feedback as reported by existing research in this area. In addition, it is not known as to how students would respond to their teacher feedback in their rewrites and how effective do students view teacher feedback is in helping them improve as ESL writers.

Therefore, it is hoped that the insights from this study will be able to help ESL teachers and students particularly in UiTM Sarawak to better improve the teaching and learning of ESL writing.

\subsection{Statement of the problem}

Most teachers would agree that it is necessary to give feedback when giving students writing assignments. Prior to the study, the researcher had an informal talk with some teachers in the context of the study concerning students' reactions towards feedback on their writing. All of them agree that giving feedback is important however, a majority of them express disappointments over students' tendency to repeat mistakes. Students' often failed to revise and would respond to their teachers' comments by making minor adjustments such as correcting grammar errors or rearranging their sentences. Students were also found to correct only mistakes highlighted by the teacher but do not actually revise their ideas.

In writing classes, feedback is viewed as essential in writing. Written comments can be given to students at any point in the writing process. It is a form of intervention and is one of the most common ways of responding to students' writing. It helps students to know whether their message or ideas is well conveyed or not. It helps students to know what their audience felt when the writing was read. It gives students the opportunity to revise, rethink and rewrite their ideas. Muncie, (1999) asserts that "feedback is vital to writing and in helping learners to improve their writing skills and whatever form it takes, it can have the positive effect of producing in the learner a sense of reader awareness and of giving him/her an outside view of texts" (p.52).

Yet, despite the perceived importance of teacher feedback and considerable attention given to it, research has remain inconclusive as to whether feedback is beneficial and effective in helping students revise and improve their writing. A lot of things are still not known such and the lack of knowledge on this poses problems to teachers and students.

This prompted the researcher to investigate and find out students' perception and preferences for teacher feedback. A majority of the students in this particular institution are weak in their command of the language. Therefore, the research hopes to find the types and forms of feedback that will help students make progress in their writing and how teachers can improve their responding behaviour to suit the students' needs and proficiency level. 


\subsection{Objective}

The objectives of this study is

(a) To identify the types of written feedback that students prefer.

(b) To identify students' perception of the written feedback they receive.

\section{Literature review}

Writing is an essential skill that every tertiary students need to possess. The ability to write and express oneself is important if students want to pass a course. It is also a necessary skill to have when students start working. However, writing is also a complex skill. To be able to write a writer "must learn how to remove redundancy...how to combine sentences, how to make reference to other elements in order to create syntactic and lexical variety and much more" (Brown 2001 p 342). As writing in the L2 requires the student to be able to master the above and much more, ESL students often face a lot of demands in writing which the student may not be able to cope with in ways a native speaker could.

A lot of early researches on teacher feedback have been based on L1 studies despite the fact that writing in L1 and L2 employs different processes. ESL students are different from native English speakers in their "Linguistic, contextual and rhetorical schemata" Reid (1994). Compared to L1 students, ESL students are dependent on their teachers to play the role of information provider and guide to help them in their writing. As for L1 students, writing is less demanding as writers are familiar with the structure and are proficient in the language. In addition, Brown (2001) reported that L2 writers "did less planning... were less fluent...less accurate and less effective in stating goals and organising materials. As such it is also necessary for teachers to help students in their language proficiency before these students are able to write confidently in the target language.

Ferris and Hedgecock (1998) stressed that L2 students often regard their teacher highly and often look up to their teachers as information providers. Hedgecock \& Leftkowitz (1996) was quoted by Ferris that "If composition teachers do not give students clear and direct feedback and instructions about how to correct and improve their texts, ESL students may feel that their instructors are incompetent or lazy or that there must be nothing wrong with their papers because they were not told what to fix." (p.133). The implication of this is, ESL writing teachers need to balance their role of judge and evaluator of students' work with being facilitator and coach. This will enhance ESL students' confidence, especially those with low English proficiency levels who face problems in communicating their thoughts in writing.

\subsection{Research on Teacher Feedback in L1}

One of the earliest researches carried out on teacher feedback in L1 was by Arnold (1964). Arnold's experimental study investigated the difference between giving feedback on all errors in the students' paper and giving feedback on one particular error paper. However, the result revealed that both treatments did not give any significant difference on student's writing ability. A similar study by Sommers (1982) investigated the way teachers respond to students' writing. In her study, she examined the responses made by 35 teachers on students' writing and found that most comments were vague, not specific, "arbitrary and idiosyncratic" (p.149). She also discovered that teachers give general comments that can "be interchanged, rubber-stamped, from text to text (p.152). This, according to Sommers is probably the reason why students do not show improvement in their revision.

Nevertheless, recent research proves that despite the negative claims, teacher feedback is reported to be most effective when given during early drafts (Ferris \& Hedgecock 1998, p. 124). In addition, Schroeder (1973) found that when positive comments were given on content, students were found to use a lot more description in their writing. Beason (1993) points out that feedback and revision are very important in the teaching of writing. He noted that students' subsequent drafts improved when they receive feedback.

\subsection{Research on Teacher Feedback in L2}

Similarly, research on teacher response in L2 found that teacher response is not effective as a tool to improve students writing. Past research found that teachers often ignore serious problems in context and are mostly concerned about pinpointing every mistakes student make. Such comments are inefficient tools for helping students (Zamel 1985). 
Despite the grim conclusion, recent research has arguments that prove otherwise. Berger (1991) in a review of research concerning teacher feedback listed a few studies that support teacher feedback as helpful in helping students. Among the studies listed were the studies carried out by Chaudron (1983), Zhang (1985), and Zhang \& Halpern (1988). These studies concluded that teacher feedback actually helps students to revise better. In addition, Keh (1990) stressed that teacher comments "are useful for pointing out specific problems, for explaining the reasons for them and for making suggestions" (p. 303). Hyland (1990) pointed out that "diligent marking provides students with an idea of the criteria by which their work is judged, and should offer useful information that will help them avoid similar errors in the future ( $p$. 279).

\subsection{Research on students' preferences on teacher feedback}

Results of early research in this area found that students seem to prefer feedback on grammar as compared to content in their writing. However, a more recent study revealed that ESL students seem to prefer feedback on both content and grammar. ESL students were also reported to value comments on form. Students were also reported to prefer comments on ideas and organization in their early drafts and comments on grammar in their later drafts (Hedgecock \& Leftkowitz (1994). Cohen \& Calalcanti (1990) discovered a similar pattern where a majority of students were found to prefer comments on content and organisation as compared to form.

In a similar study by Keh (1997), it was discovered that students prefer elaborate comments as compared to one word comments. Feedbacks that highlight specific problems and provide suggestions were also found to be most helpful. This finding is also shared by Reed \& Burton (1985) and Ziv (1984). Comments in the form of questions were also found to be effective as it pushes students to think. On the other hand, short comments such as 'good' or 'good point' were found to cause problems, as students were not sure of what they mean. This also applies to questions such as 'why'. A similar finding was reported by Lim (1994) where the students reported that feedback such as 'so', 'rewrite' and 'please explain' confused them. According to Raimes (1983), comments such as 'Revise' and anything similar do not mean anything, as they are unclear and do not provide specific direction for students.

\subsection{Contents versus Form Feedback}

Research in the area of whether to focus on form or content when giving feedback has come to various conclusions. Many researchers believed that teachers should provide comments on content and organization first before giving any comments on grammar. However, there are some who believe that concentrating on form is useful in helping students improve their writing ability. Although giving feedback on content and organisation is recommended, some researchers such as South (1998) disagrees on the basis that too many grammatical, spelling and punctuation mistakes may hinder reader comprehension of the text thus suggesting that grammar errors should be pointed out in early drafts. This is supported by Lalande (1982) who discovered that students' writing improved significantly when they were given information on the mistakes they made as compared to students whose writing were simply marked. In addition, despite recommendations by researchers to give feedback on content before form, most language teachers are reported to continue the practice of giving feedback on form (Cohen \& Cavalcanti, 1990; Fathman \& Whalley, 1990).

Researchers have also come to various conclusions on when feedback should be given. Fathman \& Whalley (1990) argued that it is not necessary for students to engage in the multiple drafts essays but others believe that feedback given in early drafts are more effective than those given in the final drafts. Zamel (1995) encourages teachers to provide comments at every draft and that teachers should prioritise their comments. Keh (1997) agreed and emphasised that teachers should "limit comments according to fundamental problems". Furthermore, Keh recommended that teachers respond as an interested reader and not as an evaluator of students' work in order to be effective in giving feedback. In Keh's study, students were reported to read their teacher's comments because "they wanted to know what they did well and how they could improve" (p. 302). Students were also reported to read comments first and they also find praise very important.

The practice of giving both praise and criticism has been proven to help enhance students' writing (Cardelle \& Corno 1981). The researchers advocate that teachers "provide specific feedback on [composition] that identifies students' errors, guides the students toward a better attempt next time and provides some positive comments on work particularly well done" (p. 260). Nevertheless some researchers found that giving too much praise may hinder students from revising. Students may misinterpret praise as a signal for them to keep their text as it is. Praise may also mislead students into thinking that they deserve a higher mark for their writing. Therefore it is necessary that praise be balanced 
with criticism. Ferris (1995) found that L2 writers expect their teachers to provide them with criticism in addition to praise. These students were reported to appreciate and remember praise and at the same time expect to receive constructive criticism.

In another similar research carried out by Ellen Lipp (1995), it was discovered that more than 90\% of the students achieved higher scores on revision when the teachers provide feedback on both content along with a few comments on grammar, spelling and punctuation. Lipp's study, which incorporated the use of praise, questions and encouragement, found that students respond to teacher feedback positively and revise better in their content. Leki (1992) shares this view and stresses that teachers write comments on content with a limited amount of feedback on grammar punctuation and spelling.

The information gathered from these researches proves significant to both teachers and learners of English. They suggest that it is necessary for teachers to provide a balance of both feedback on content and form in order to help students improve.

\subsection{Research on Students' Perceptions of Teacher Feedback}

Leki (1990) conducted a survey on students' perception on teacher feedback. The study established that the samples ignored their teachers' feedback; often finding teacher feedback hard to comprehend, as well as feeling a sense of hostility when teachers correct their writing. The possibility that students may not read the feedback given could not explain its ineffectiveness in helping students. Burkland and Grimm (1986) found that students are more interested in their grades rather than the comments given by their teachers. In a survey research in L2, conducted by Cohen (1987) on a single draft writing suggested that 'the activity of teacher feedback as currently constituted and realised may have a more limited impact than the teachers would desire' ( $p .66$ ). Participants of this study were found to use 'a limited repertoire of strategies for processing teacher feedback'. A majority only made mental notes of the teacher's comments and some did nothing at all (p. 65). The findings of this study showed that students did not do much to revise their writing. Most of them reread their papers but quite a number reported that they did not.

The same result was also shared by Leki (1991b; Radecki \& Swales, 1988). However, Ferris (1995) and Sim (1997) discovered a more encouraging result as she found that students do use a variety of strategies to revise their essays. Students were reported to use outside sources as well as consulting their tutors, checking up the dictionary and grammar books, along with asking their friends. A similar study carried out by Cohen \& Cavalcanti (1990), reported that students view their teacher's feedback as helpful. Students were also found to pay a great attention to teacher feedback and there was a good match between the types of feedback students prefer and the types of feedback that the teacher gave them. Ferris (1995) also reported that students received feedback on grammar along with content in their early drafts. Her study also found that students pay more attention to the comments given in the early drafts. Positive comments are appreciated and on a whole, the students believed that their teacher's comments are useful in helping them to improve their writing.

\section{Research methodology}

\subsection{Participants}

34 students, 29 females and 5 males, from an intermediate ESL class at the Faculty of Accountancy of the Universiti Teknologi MARA participated in the study whose age range from 18-20 years old. Convenience sampling was used to select the respondents.

\subsection{Instrument}

The instrument used in this study was a questionnaire adapted from Ferris (1995) Leki (1999) and Hedgecock and Leftkowitz (1994) and consisted of 27 items each item in the questionnaire tries to address a particular issue in teacher feedback. They can be divided into three major categories namely students' demographic data, students' perception of feedback they receive and students' preferences of the types of feedback they receive. 


\section{Findings and discussion}

Table 1. Students' perception of the nature of teacher feedback

\begin{tabular}{|c|c|c|c|c|}
\hline $\begin{array}{c}\text { How many of your teacher's comments and } \\
\text { correction involve: }\end{array}$ & A lot & Some & A little & None \\
\hline - $\quad$ Organization & $12 \%$ & $32 \%$ & $47 \%$ & $9 \%$ \\
\hline - Content/Ideas & $12 \%$ & $53 \%$ & $12 \%$ & $24 \%$ \\
\hline - $\quad$ Grammar/language use & $74 \%$ & $21 \%$ & $6 \%$ & $0 \%$ \\
\hline - Vocabulary & $29 \%$ & $38 \%$ & $24 \%$ & $32 \%$ \\
\hline - Mechanics & $17 \%$ & $32 \%$ & $32 \%$ & $18 \%$ \\
\hline
\end{tabular}

A high percentage of the students prefer that the teacher provide suggestions (85\%). Another $71 \%$ of the students prefer that their teacher provide them with the correct form or correct answers for their errors. $62 \%$ of the students prefer that the teacher identifies all the errors they made while $21 \%$ would like their teacher to provide them feedback in the form of questions. Finally only one student reported that the teacher provide positive comments.

Table 2. Students' perceptions of the effectiveness of teacher feedback in helping them improve as writers

\begin{tabular}{|l|c|}
\hline \multicolumn{2}{|l|}{ Do you feel that your teacher's comments and corrections are effective in helping } \\
you to improve your composition writing skill? Why? & Percentage (\%) \\
\hline Effective & 15 \\
$-\quad$ Teacher comments are the key to improve my writing skill. & 12 \\
$-\quad$ A reminder so as to avoid similar mistakes. & 18 \\
$-\quad$ Yes, so that I know my mistake and weaknesses. & 29 \\
$-\quad$ It motivates and helps me write better. & 3 \\
- It helps improve my desire to write, my ability to read and my work is not & 3 \\
in vain when teacher comments on my work. & \\
- I seldom refer to it thoroughly. & 12 \\
\hline
\end{tabular}

A high percentage of the students believe that teacher comments are effective in helping them improve (94\%). They felt that teacher is important and expresses that "it helps me improve because it is the key to improve my writing skill". Some students also claim that the presence of the teacher feedback show that their work has been appreciated and read by the teacher. Other students claim that the teacher feedback helps them to think and teaches them how to write properly. 18\% believes it motivates them to write better.

Table 3. Comments students' perceive as most helpful in helping them improve their composition.

\begin{tabular}{|l|c|}
\hline $\begin{array}{l}\text { Which specific comments did you find most helpful in improving your } \\
\text { composition? Least helpful? Why? }\end{array}$ & $\begin{array}{l}\text { Percentage } \\
(\%)\end{array}$ \\
\hline Most helpful comments & 26 \\
- Suggestions & 18 \\
- Highlighting all my errors & 15 \\
- Comments on grammar & 6 \\
- Criticism & 21 \\
- Praise & 9 \\
- Providing correct answers for my mistakes & 6 \\
- Asking questions & 3 \\
\hline
\end{tabular}

A significant number of students reported that comments in the form of suggestions helped them improved most (26\%). These students perceive that suggestions helped them by providing new ideas and new ways to rewrite their essays. The 
also reported that suggestions aid them I organizing a better draft part from acting as guidance. This view is consistent with students' preferences for comments in the form of suggestions as discussed above.

Table 4. Comments students' perceive to be least helpful in helping them improve their composition.

\begin{tabular}{|l|c|}
\hline Which specific comments did you find most helpful in improving & Percentage (\%) \\
your composition? Least helpful? Why? & \\
\hline Least helpful comments & 18 \\
- One-word comments & 24 \\
- $\quad$ Puestions & 3 \\
- Praise & 15 \\
- $\quad$ Suviding the correct answers & 6 \\
- Comments on organization & 3 \\
- Comments on vocabulary & 6 \\
- Negative comments & 6 \\
- Comments without suggestions & 3 \\
- Comments that does not include grammar & 3 \\
- No, there are no comments that are not helpful & 15 \\
\hline
\end{tabular}

Table 5. Students' preferences of teacher feedback form

\begin{tabular}{|c|c|}
\hline What types of comments and corrections do you prefer on your paper? & $\begin{array}{c}\text { Percentage (\%) } \\
n=34\end{array}$ \\
\hline $\begin{array}{ll} & \text { Asking questions } \\
\text { - } & \text { Giving suggestions } \\
\text { - } & \text { Identifying all errors } \\
\text { - } & \text { Writing the correct answer over errors made } \\
\end{array}$ & $\begin{array}{c}21 \% \\
85 \% \\
62 \% \\
71 \% \\
3 \%\end{array}$ \\
\hline
\end{tabular}

A significant number of students reported that comments in the form of suggestions helped them improved most (26\%). These students perceive that suggestions helped them by providing new ideas and new ways to rewrite their essays. The also reported that suggestions aid them I organizing a better draft part from acting as guidance. This view is consistent with students' preferences for comments in the form of suggestions as discussed above.

Table 6. Students' preferences on comments and corrections

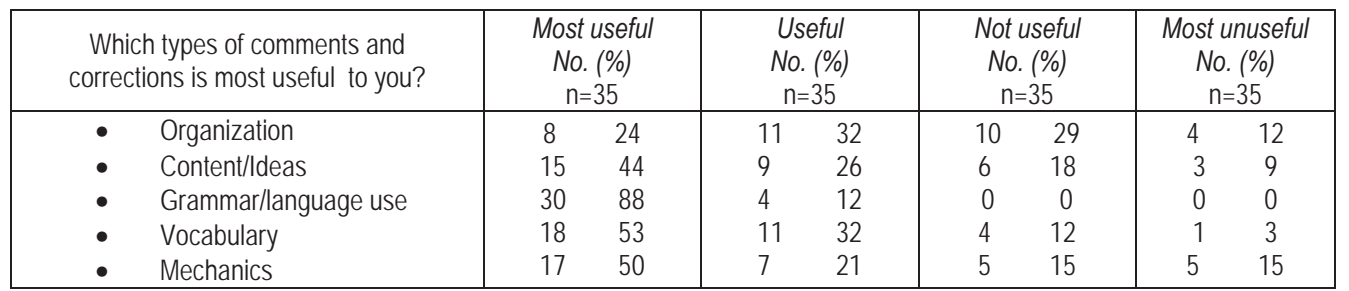

Results from the study revealed that a significant number of students reported that they found comments regarding grammar most useful. More specifically, $88 \%$ of the students reported grammar as most useful. This is followed by vocabulary where $53 \%$ of the students reported it is most useful and $32 \%$ reported it as being useful. As for mechanics, $71 \%$ reported it is useful and $21 \%$ 'useful'. $70 \%$ of the students claim that comments on content/ideas are most useful and $26 \%$ reported it is useful. Finally, $56 \%$ of the students view organization as most useful and $32 \%$ useful.

The findings from this study indicated that students read their teacher's feedback because they view teacher feedback as important and necessary in helping them know their strength and weaknesses in writing. They were also found to expect their teacher to provide them with feedback as the lack of it shows that the teacher does not appreciate the efforts they put in writing. Additionally, students reported that they received a significant amount of feedback on 
grammar. They also reported that they pay a lot of attention to grammar. This may be the result of the emphasis on grammar in the course. In addition, grammar is perceived to be important as it is viewed to help make sentences and compositions clearer.

Students also indicated an overwhelming preference for comments in the form of suggestion. Suggestion is perceived to help by giving ways and ideas of making improvements in their compositions. Apart from that, suggestion is viewed as a way for helping them to solve their writing problems and organise a better draft. In addition, comments that were framed as guidance and presented in positive ways were also found to offer help in their revisions. The findings also indicate that questions and one-word comments are viewed as the least useful type of feedback. It was reported by the students that such comments confused them and hinders them from making appropriate revision as they do not know what the teacher experts them to do. It was also found that students values both positive and negative comments. Negative comments did not hinder students from making progress but was welcomed as a challenge to push them to do better.

\section{Concluding Remarks}

The results and findings of this study suggest that, teachers need to think about their comments more thoroughly before putting them on students' paper. It may also be necessary that teachers complement written feedback with teacher student conferences or other forms of feedback that will help low proficiency students make appropriate development in writing. Furthermore, "students must also be trained to use the feedback in ways that will improve their writing" (Kroll 2001, p.227). As research and theory has advocated, teachers may need to balance both grammar and content feedback. In the case of students in this study, a lot of emphasis are placed on grammar in their course. Therefore they felt that they need feedback on grammar as it helps make their sentences and compositions clearer and is also important in their exams. Furthermore this study suggests that students appreciate both positive and negative comments. They perceive both of feedback as a source of motivation, and challenge that pushes them to do better in future compositions. It is therefore necessary that teacher provide students with feedback that praises their strength and constructive comments that highlight their weaknesses in order to avoid repetition of mistakes in future writings (Cardelle\& Corno, 1981). Finally, it seems that students in this study prefer comments that are elaborate and specific. This implies that teachers need to show genuine interest in the students' composition and respond to it by referring to specific points or details written in the piece as elaborate and specific comments were found to generate positive changes in students' rewrites (Ferris, 1997).

\section{References}

Boughey, C. (1997). Learning to write by writing to learn: a group work approach. ELT Journal Volume 51/2 Oxford University Press.

Cardelle, M. \& Corno, L. (1981). Effects on Second Language Learning of Variations in Written Feedback on Homework Assignment. TESOL Quarterly, 251-261.

Charles, M. (1990). Responding to Problems in Written English using a student self-monitoring technique. ELT Journal Volume 44/4, 286-290.

Chaudron, C. (1984). The Effects if Feedback on Students' Composition Revision. RELC Journal Volume 15, No. 2, 1-4.

Cohen, A., D. \& Cavalcanti, M., C. (1990). Feedback on Composition: Teacher-Student verbal Reports. In B. Kroll Second Language Writing Research. Cambridge, Cambridge University Press.

Cohen, A., D. (1987). Students Processing of Feedback on Their Compositions. In Wenden \& Rubin, Learner Strategies in Language Learning Prentice Hall, UK.

Connors, R. J., \& Lunsford, A.A. (1993). Teacher's Rhetorical feedback on students' papers. College Compositions and Communications. Vol. 44/1, 200-223.

Dheram, P., K. (1995). Feedback as a Two Bullock Cart: A case study of teaching Writing. ELT Journal Volume 49/2, 160-168.

Ferris, D. \& Hedgehock (1998). Teaching ESL Composition: Purpose, Process \& Practise. Mahwah, NJ: Lawrence Erlbaum.

Ferris, D. (1997). The influence of teacher commentary on student revision. TESOL Quarterly, 31/2, 315-339.

Ferris, D. (1995). Student reactions to teacher response in multiple draft composition classrooms. TESOL Quarterly, 29/1, 33-53.

Faigley, L. \& Witte, S. (1996). Analyzing Revision. In Allyn \& Bacon Sourcebook For College Writing Teachers. Allyn \& Bacon, Massachusettes.

Frankenberg-Garcia, A. (1999). Providing students writers with pre-text feedback. ELT Journal Volume 53/2, 100-106.

Gee, T. (1972). Students' responses to teacher comments. Research in the Teaching of English, 6, 212-219.

Grabe, W. \& Kaplan, R., B. (1996). Theory and Practice of writing. London: Longman.

Hedge, T. (1998). Writing. Oxford University Press, Oxford.

Hyland, Ken. (1990). Providing Productive Feedback. ELT Journal Volume 44/4, 279-285. 
Keh, C. L. (1990). Feedback in the writing Process. A Model and Methods for Implementation. ELT Journal Volume 44/4, $294-304$.

Knoblaunch, C. H., \& Brannon, L. (1981). Teacher commentary on student writing: The state of the art. Freshman English News, 10, 14.

Kroll, B. (2001). Considerations for Teaching an ESL/EFL Writing Course. In Celce-Murcia, M. (Ed) Teaching English as a Second or Foreign Language ( $3^{\text {rd }}$ ed) Heinle \& Heinle: USA

Lalande, J. F. (1982). Reducing composition errors. An experiment. Modern Language Journal, 66, 140-149.

Leki, I. (1990). Coaching from the Margins: Issues in written Response. In B. Kroll Second Language Writing Research. Cambridge, Cambridge University Press.

Lim, S. K. (1994). A Case study of a teacher's written responses to ESL composition. M Ed Research Report, University of Malaya.

Lipp, E. \& Davies-Ockey, D. (1997). Praise - Question-Encourage: Guidelines for writing teacher comments between essay drafts. Forum Volume 35, 12-16.

Muncie, J. (2000). Using written teacher feedback in EFL composition classes. ELT Journal Volume 54/1, 47-53.

Raimes, A. (1983). Techniques in Teaching Writiing. Oxford University Press. New York.

Reed, W. M., \& Burton, J. K. (1985). Effective \& ineffective evaluation of essays: Perceptions of college Freshman. Journal of teaching writing, 4, 270-282.

Reid, J. (1994). Responding to ESL Students' Texts: The Myths of Appropriation. TESOL Quarterly 28 (2) 273-292.

Roskams, T. (1999). Chinese EFL students' attitudes to Peer Feedback \& Peer Assessment in an Extended Pair work Setting. RELC Journal Volume 30. No.1, 79-102.

Silva, T. (1990). Second Language Composition Instruction, Developments Issues \& Directions in ESL. In B. Kroll Second Language Writing Research. Cambridge, Cambridge University Press.

Sim, P. L. S. (1997). Teacher Comments and Student Reactions in Multiple draft Composition. M ed Research Report, University of Malaya.

Sommers, N. (1987). Revision Strategies of student Writers \& Experienced Adult Writers. In Enos, T. A Sourcebook for Basic Writing Teachers. Random House. New York.

Sommers, N. (1992). Composing and revising (Between the drafts) In College composition \& Communication 43 (1992): 22-31. In Corbett, E. P. J. et.al (2000) The writing Teacher's Sourcebook (4th ed) Oxford University Press.

South, C. (6 March 1998) The writing teacher's friend: An Editing checklist for students. Retrieved 27 March 2003 from

http://langue.hyper.chubu.ac.jp/jalt/pub/ttl/98/mar/south.html

Straub, R. (1996). Students' reaction to teacher feedback: An exploratory study. Research in the Teaching of English, 3/11, 91-119.

Vengadasamy, R. (2002). Responding to students writing: Motivate, not criticize. Online Journal of Language Studies. Retrieved 23 August 2003 from

http://www.fpbahasa.ukm.my/journal.20020203.htm

Witbeck, M. C. (1976). Peer correction procedures for intermediate \& Advanced ESL Composition lesson. TESOL Quarterly Volume 16. No.3.

Zamel, V. (1982). Writing. The process of discovering meaning. TESOL Quarterly, 16, 195-209.

Zamel, V. (1985). Responding to student writing. TESOL Quarterly, 19, 79-102.

Ziv, N. (1985). The effect of teacher comments on the writing of four college freshmen. In R. Beach, L. Bridwell, (Eds.), New directions in composition research (pp. 362-380). New York: Guilford. 